\title{
Herbal Plants: The Role of AhR in Mediating Immunomodulation
}

\author{
Izzah Bungsu, Nurolaini Kifli, Siti Rohaiza Ahmad, Hazim Ghani \\ and Anne Catherine Cunningham*
}

Pengiran Anak Puteri Rashidah Sa'adatul Bolkiah (PAPRSB), Institute of Health Sciences, Universiti Brunei Darussalam, Bandar Seri Begawan, Brunei

The prevalence of chronic inflammatory diseases including inflammatory bowel disease (IBD), autoimmunity and cancer have increased in recent years. Herbal-based compounds such as flavonoids have been demonstrated to contribute to the modulation of these diseases although understanding their mechanism of action remains limited. Flavonoids are able to interact with cellular immune components in a distinct way and influence immune responses at a molecular level. In this mini review, we highlight recent progress in our understanding of the modulation of immune responses by

OPEN ACCESS

Edited by:

Harry D. Dawson,

Agricultural Research Service,

United States Department of

Agriculture, United States

Reviewed by:

David Shepherd,

University of Montana, United States Akihiro Kimura,

National Center For Global Health and Medicine, Japan

*Correspondence: Anne Catherine Cunningham anne.cunningham@ubd.edu.bn

Specialty section:

This article was submitted to Mucosal Immunity,

a section of the journal

Frontiers in Immunology

Received: 20 April 2021 Accepted: 08 June 2021 Published: 24 June 2021

Citation:

Bungsu I, Kifli N, Ahmad SR, Ghani H and Cunningham AC (2021) Herbal Plants: The Role of AhR in Mediating Immunomodulation.

Front. Immunol. 12:697663. doi: 10.3389/fimmu.2021.697663 the aryl hydrocarbon receptor (AhR), a ligand-dependent transcription factor whose activity can be regulated by diverse molecules including flavonoids. We focus on the role of AhR in integrating signals from flavonoids to modulate inflammatory responses using in vitro and experimental animal models. We also summarize the limitations of these studies. Medicinal herbs have been widely used to treat inflammatory disorders and may offer a valuable therapeutic strategy to treat aberrant inflammatory responses by modulation of the AhR pathway.

Keywords: AhR, flavonoids, immune response, immunomodulatory, herbal plants

\section{INTRODUCTION}

Aberrant activation of immune responses is an underlying cause for the development of chronic inflammatory diseases which either excessively activate immune cells that contribute to tissue damage or suppress immune cells and enable cancer cell proliferation and metastasis (1). Non-toxic herbal compounds such as flavonoids have been shown to induce protective effects against multiple chronic inflammatory diseases (2) including $\operatorname{IBD}(3)$, autoimmunity $(4,5)$ and cancer $(6,7)$. Understanding the molecular mechanisms of flavonoids and their potential pathways is crucial to identify therapeutic targets for more effective and safer interventions for inflammatory diseases.

Flavonoids are polyphenols, acting as the main bioactive metabolites in various plants, which contribute to the color, taste as well as pharmacological and biochemical effects (8). Good sources of flavonoids include plant-derived food such as fruits, vegetables, tea, cocoa products, nuts, legumes, and herbal plants (8).

Flavonoids have a broad range of structures depending on the position of the carbon in the $\mathrm{C}$ ring to which the $\mathrm{B}$ ring is attached, and the degree of saturation and oxidation of the $\mathrm{C}$ ring (Figure 1). Flavonoids can be categorized into six major groups from a structural standpoint, namely flavonols, flavones, isoflavones, flavonones, flavanols and anthocyanidins (9). 


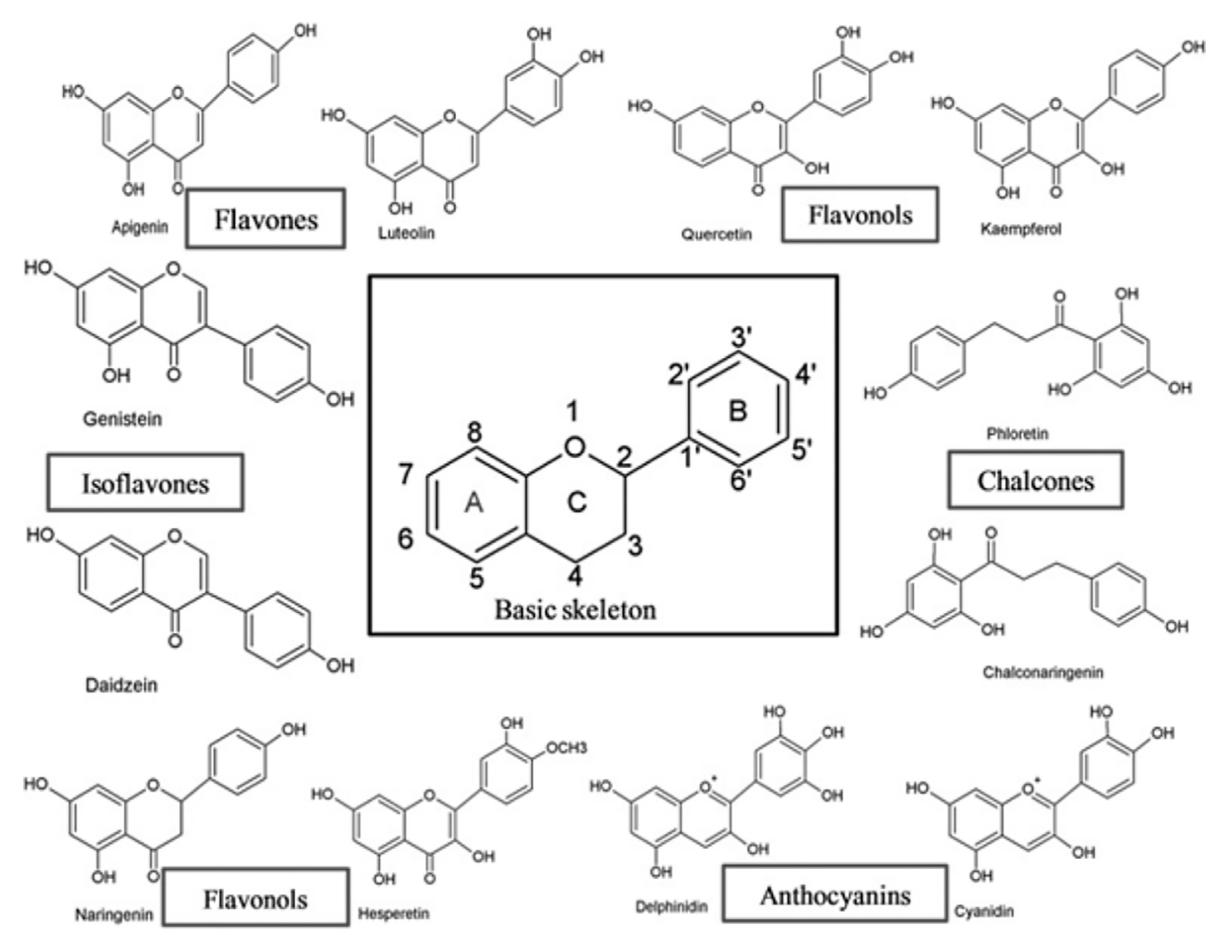

FIGURE 1 | The basic skeleton structure of flavonoids and six major classes of flavonoids (9).

Numerous in vitro and in vivo studies have demonstrated the health-promoting effects flavonoids possess including antioxidant, anti-inflammatory and immunomodulatory properties $(2,9)$. The mode of action of flavonoids include their ability to directly interact with immune cells, modify the production of cytokines and inhibit inflammatory signaling pathways (10). For example, fisetin (a flavonol) was found to inhibit maturation and activation of dendritic cells and inhibit Th1 polarization by significantly inhibiting the expression levels of costimulatory proteins CD40, CD80, CD86 and MHC Class II in a dose-dependent manner (11). Similar effects have been observed in dendritic cells harvested from mouse bone marrow using quercetin (another flavonol) (12). In a murine model of experimental autoimmune thyroiditis (EAT), luteolin (a flavone) led to decreased lymphocyte infiltration by inhibiting interferon- $\gamma$-induced COX- 2 and pro-inflammatory cytokine tumor necrosis factor- $\alpha$ (TNF- $\alpha$ ) (13). Apigenin (a flavone) has been demonstrated to decrease colonic damage scores and colonic weight/length ratio in a rat model of colitis (14). Oral administration of apigenin resulted in normalization of some colonic inflammatory markers such as TNF- $\alpha$, transforming growth factor $\beta$ (TGF- $\beta$ ) and interleukin-6 (IL-6) (14). Genistein (an isoflavone), kaempferol, quercetin (a flavonol), and daidzein (an isoflavone) were shown to inhibit STAT-1 and NF- $\kappa \mathrm{B}$ activation (15). Interestingly, flavonoid metabolism in the gut also modulates intestinal immune responses via the activation of T-cell differentiation, gut microbiota alteration and cytokine production (16). This highlights the importance of dietary interventions containing flavonoids to combat human chronic diseases (16). However, less is known about how flavonoids regulate immune components and immune signaling pathways at a molecular level. Structural studies reveal that flavonoids are ligands of the aryl hydrocarbon receptor (AhR) (17-19).

\section{ARYL HYDROCARBON RECEPTOR (AhR)}

$\mathrm{AhR}$ is a ligand-dependent transcription activator that responds to a variety of molecules from the environment including dietary, metabolic products and pollutants (20). This protein was first identified as the dioxin receptor that mediates biotransformation and elimination of harmful xenobiotics, it's activation leading to toxicity and tumor development $(21,22)$. AhR is increasingly recognized as an important immune modulator implicated in many chronic inflammatory diseases (23).

The inactive form of AhR resides in the cytoplasm, complexed with several chaperone proteins such as heat-shock protein (HSP90), p23 (17), c-SRC and AhR interacting protein (AIP) (20, 24, 25). Upon binding with environmental ligands, AhR translocates to the nucleus which leads to heterodimerization with the AhR nuclear translocator (ARNT). AhR-ARNT complex binds to the xenobiotic response element (XRE) in regulatory genes to induce specific transcription of gene expression including drug and ligandmetabolizing enzymes such as CYP1A1, CYP1A2 and CYP1B1 and AhR repressor (AhRR). This pathway is tightly controlled through proteasomal degradation of AhR ligand metabolism by CYP1A1, and AhR/ARNT complex disruption by AhRR (26). 
AhR can also interact with other transcriptional regulators including retinoblastoma protein $(\mathrm{Rb}), \mathrm{NF}-\mathrm{kB}$, the estrogen receptor and modulate their activity (27). AhR interaction with $\mathrm{Rb}$ leads to cell cycle arrest in the G1-phase in several cell lines (28), while AhR interaction with NF- $\mathrm{KB}$ induces the expression of cytokines and chemokines such as B-cell activating factor of TNF family (BAFF), CXCL13, CCL1 and the transcription factor interferon responsive factor 3 (IRF3) (29). It has been shown that 2,3,8,7-tetradichlorobenzo-p-dioxin (TCDD)-mediated AhR activation led to its recruitment to a non-consensus XRE, ie E2Fregulated-S phase loci (30). Kruppel-like factor 6 (KLF6) is another AhR-DNA binding partner recently reported (31). KLF6 is a tumor suppressor and it's mutations have been associated with a number of cancers such as hepatocellular carcinoma, gastric and colon cancers (31). KLF6 activates p2 $1^{\text {cip } 1}$ via an AhR-dependent mechanism which leads to the inhibition of cell cycle progression (32). In addition, AhR has also been demonstrated to control biological processes through the regulation of retrotransposons, micro-RNAs and long non-coding RNAs which are known to regulate multiple target genes (33).

AhR can influence chromatin architecture by interacting with Brahma/SWI2-related gene 1 (Brg1) subunit of the SWI/SNF chromatin-remodeling complex (34). AhR can also affect local histone hyperacetylation and methylation either by directly interacting with coactivators such as the steroid receptor coactivator-1 (SRC-1) complex (35) or by displacing histone deacetylase (HDAC) complexes (36).

There have also been reports that show AhR can act independently of ligand activation under certain conditions $(37,38)$. However, the physiological relevance of these observations remain to be evaluated. Overall, activation of AhR by a ligand can induce non-genomic and genomic pathways that promote transcriptional events and modulation of myriad biological processes including immune responses. Through both mechanisms, AhR targets specific gene expressions associated with inflammation including $\mathrm{NF}-\kappa \mathrm{B}$, immune regulatory and growth factors (20). AhR is also able to control the differentiation of several cell types in the immune system including innate dendritic cells (DCs), macrophages and natural killer cells (39) and adaptive $\mathrm{B}$ and $\mathrm{T}$ cells relevant to inflammation (40-45).

\section{AhR EXPRESSION}

AhR is widely expressed throughout the body particularly in the liver, placenta (46) and in epithelial barriers such as the skin, gut and lung mucosa (47). AhR is also highly expressed by multiple cell types at these barrier sites including intestinal epithelial cells (IECs) (48), intraepithelial lymphocytes (IELs) (49), innate lymphoid cells (ILCs) (50) and intraepithelial CD8 $\alpha \alpha$ expressing lymphocytes (49). AhR levels are very low in naïve $\mathrm{T}$ and $\mathrm{B}$ cells, Th1 and Th2 helper T cells, moderate in natural killer (NK) cells but very high in Tregs, Th17 cells $(24,25,39$, 47), B cells $(51,52)$ and DCs (53-57). AhR expression is also pronounced in unconventional peripheral $\gamma \delta$ T cell subsets such as TCR $\gamma 1, \mathrm{TCR} \gamma 2, \mathrm{TCR} \gamma 3, \mathrm{TCR} \gamma 4, \mathrm{TCR} \gamma 5$ and TCR $\gamma 6$ (58). Systemic $\mathrm{V} \gamma 5$-expressing $\gamma \delta \mathrm{T}$ cells produce IL-22 in response to AhR activation (59) while epidermal $\mathrm{V} \gamma 3$ and intestinal $\mathrm{V} \gamma 5$ expressing $\gamma \delta \mathrm{T}$ cells require AhR for survival as studies in AhRdeficient mice showed they were lacking these subsets (26). V $\gamma 4$ expressing $\gamma \delta \mathrm{T}$ cells which are predominant in the lungs, reproductive tract and oral mucosa express very high levels of AhR. However, these cells are not reduced in AhR deficient mice suggesting they may also have different roles (26). Overall, AhR has become a key player in maintaining tissue integrity, tissue repair and immune protection against environmental challenges, particularly at epithelial barrier sites.

\section{AhR LIGANDS}

Numerous AhR ligands have been identified which consist of xenobiotic compounds and natural compounds that are derived from food and host/microbiome metabolism $(17,18)$. Many of these ligands have been shown to impact on immune responses via modulation of immune cell function and differentiation.

The first prototypical AhR ligand studied was TCDD (21), an environmental contaminant that has intrigued toxicologists for decades. Early studies mostly focused on the immune toxicity and carcinogenic effects of TCDD in humans and animal models. It has profound immunosuppressive effects that are undesirable as it increases susceptibility to bacterial and viral infections and tumor growth (60). Other reported effects include thymic involution, depletion of lymphoid organs, thymocyte and T cell apoptosis $(26,61)$. However, during inappropriate immune responses, the effects of AhR activation by TCDD seem beneficial for preventing development of diseases such as allograft rejection, allergic responses, autoimmunity including type 1 diabetes (60). TCDD has been shown to suppress Th1, Th2 and Th17-cell mediated responses and promotes the development of Tregs by a TGF- $\beta$-dependent mechanism $(25,41,60)$.

Tryptophan (Trp) amino acid metabolism is an emerging key family of AhR ligands. Degradation of Trp via enzymes including indoleamine 2,3-dioxygenase (IDO) and tryptohan 2,3dioxygenase (TDO), photo-oxidation and bacterial degradation generate distinct AhR agonist ligands such as kynurenine (Kyn), 6-formylindolo[2,2-b]carbazole (FICZ) and indoles respectively. It has been reported that Kyn is produced in glioma cells and has been shown to promote the differentiation of Tregs and promote immunosuppression in the tumor microenvironment (62). Photo-oxidation of Trp to FICZ has been shown to impact immune responses in an experimental autoimmune encephalitis (EAE) mouse model (24). The activation of AhR by FICZ interfered with Treg cell development, boosted Th17 cell differentiation and increased the severity of EAE in mice (41). Interestingly, AhR activation by FICZ also strongly promotes expression of IL-22 $(63,64)$ which is a member of the IL-10 family of cytokines. Although IL-22 has been shown to be proinflammatory and can induce skin inflammation $(65,66)$, it has also been reported to prevent tissue damage and aids in repair of 
the gastrointestinal tract. Bacterial degradation of Trp to produce indole metabolites such as indole-3-aldehyde (IAld) has been demonstrated by Lactobacillus species in the intestine (67). Zelante et al. demonstrated that activation of AhR by lald helps maintain intestinal homeostasis and prevents colonization by pathogenic microorganisms such as Candida albicans and inhibits development of inflammatory disorders such as IBD and cancer (67). Deficits in commensal bacteria producing Trp-derived AhR agonist may contribute to the pathogenesis of human IBD (68).

Dietary factors can also be a source of AhR ligands. Vegetables such as broccoli, cauliflower, Brussel sprouts and cabbages contain indole-based glucobrassicin $(24,26)$ which can be converted into AhR agonist precursors such as indole-3carbinol (I3C) and indole-3-acetonitrile (I3ACN) by chewing. I3C and I3ACN can be further converted into AhR activating metabolites such as 3,3'-di-indolyl-methane (DIM), [2-(indol-3ylmethyl)-indol-3-yl] indol-3-ylmethane (LTr1), and indolo[3,4b] carbazole (ICZ) (69). These dietary compounds have been shown to promote maintenance of the intraepithelial lymphocytes (IELs) and innate lymphoid cells (ILCs) allowing cell proliferation, immune surveillance and modulation of the gut inflammation (69). Other therapeutic effects of I3C and its precursors reported include modulation of inflammation in experimental animal models of multiple sclerosis (70) and other murine models (48) via AhR-dependent induction of FoxP3 regulatory T cells.

Natural compounds from plants have also been reported to be ligands for AhR. Indirubin and indigo are phytochemicals with mild AhR agonistic activity. Their concentrations may be too low to be considered as relevant physiological ligands, however their dietary accumulation may have the potential to affect AhR activation and contribute to the maintenance of mucosal integrity in the gastrointestinal tract (24). A study by Kawai et al. on murine dextran sulfate-induced colitis showed increased mRNA expressions of IL-10 and IL-22 following indigo treatment derived from herbal plants (71). The group also showed the expansion of IL-10 producing CD4+ T cells and IL-22 producing CD3-ROR $\gamma \mathrm{t}$ cells, but interestingly not CD4+FoxP3+ regulatory $\mathrm{T}$ cells in C57BL/6J mice (71). Indigo is a potent inducer of IL-10 and IL-22 that protects against highfat diet (HFD)-induced insulin resistance in a C57BL/6J dietinduced obesity murine model that is linked to a reduction in harmful inflammatory immune cell accumulation in the intestine, visceral adipose tissue and liver (72).
Flavonoids are another group of phytochemicals that are thought to be important ligands of AhR. They have been demonstrated to confer protective effects in a range of AhRdependent in vitro and in vivo models associated with ulcerative colitis, allergy and cancer. Flavonoids have been shown to control inflammatory responses by inhibiting certain inflammatory pathways, downregulating pro-inflammatory cytokines and promoting tolerogenic immune responses by AhR dependent mechanisms (Table 1). Activation of AhR by a non-toxic flavonoid, $\beta$-naphthoflavone $(\beta N F)$ was observed to reduce the severity of colitis in a murine model through inhibition of NF- $\kappa \mathrm{B}$ pathway and pro-inflammatory cascade of cytokines (73). Activation of AhR by cardamonin (a flavone) isolated from Alpinia katsumadai Hayata seeds, significantly improved the condition of male $\mathrm{C} 57 \mathrm{BL} / 6 \mathrm{~J}$ and $\mathrm{BALB} / \mathrm{c}$ mice through inhibition of NLRP3 inflammasome activation (74). Alpinetin (a flavone) also isolated from Alpinia katsumadai Hayata seeds alleviated colitis through restoring Th17/Treg balance in the colon via activation of AhR. In vitro assays showed alpinetin induction of Treg differentiation but less effect was observed on Th17 differentiation in this study (75). Activation of AhR by naringenin (a flavonone) commonly found in grapefruit promoted the differentiation of Tregs in murine models of allergy (76). Interestingly, AhR also contributes to flavonoid metabolism and this will affect bioavailability in vivo. AhR activation upregulates gene expression of xenobiotic enzymes creating positive feedback loops. The xenobiotic enzymes can be distinguished into phase 1 and phase II enzymes. Phase 1 enzymes mediate oxidation, reduction and hydrolysis reactions, and flavonoid metabolism occurs mainly in the intestine (77). The cytochrome P450 (CYP450) family are crucial to phase 1 biotransformation of flavonoids. Once flavonoids enter intestinal epithelial cells, phase II enzymes produce the corresponding conjugated metabolites. Three types of phase II enzymes are reported to metabolize flavonoids, uridine-5'-diphosphateglucuronosyltransferases (UGT), sulfotransferases (SULT), and catechol-O-methyltransferases (COMT) $(78,79)$. Phase II conjugation also occurs in the liver where flavonoids can be further conjugated (e.g., sulfation/methylation) (79) then transported to the portal vein or lymphatics. In addition, the gut microbiota also contribute to flavonoid metabolism (80) and may compensate for phase 1 and phase II enyzmes (79).

The role of $A h R$ in cancer remains unclear. Many investigators speculate $\mathrm{AhR}$ is a double-edged sword that can either act as a tumor suppressor or promoter. Flavonoids exhibit

TABLE 1 | Effect of flavonoids-induced immunomodulation via AhR.

\begin{tabular}{|c|c|c|c|c|}
\hline Flavonoid & Type of study & Disease involved & Mechanism & References \\
\hline$\beta N F$ & In vivo & Colitis & $\begin{array}{l}\text { Inhibition of NF- } \mathrm{kB} \text { pathway } \\
\text { Inhibition of pro-inflammatory cytokines TNF- } \alpha \text {, IL- } 6 \text { and IL-12 }\end{array}$ & (73) \\
\hline Cardamonin & $\begin{array}{l}\text { In vitro } \\
\text { In vivo }\end{array}$ & $\begin{array}{l}\text { Cell line }(T H P-1) \\
\text { Colitis }\end{array}$ & $\begin{array}{l}\text { Inhibition of NLRP3 inflammasome activation } \\
\text { Inhibition of pro-inflammatory cytokines such as IL-1 } \beta, \text { TNF- } \alpha\end{array}$ & (74) \\
\hline Alpinetin & $\begin{array}{l}\text { In vivo } \\
\text { In vitro }\end{array}$ & $\begin{array}{l}\text { Colitis } \\
\text { Cell isolation (colonic lamina propria) }\end{array}$ & $\begin{array}{l}\text { Restoration of Th17/Treg balance } \\
\text { Induce differentiation of Treg and less effect on Th17 differentiation }\end{array}$ & (75) \\
\hline Naringenin & In vivo & Allergy & Induced Treg differentiation & $(76)$ \\
\hline
\end{tabular}


AhR agonist or antagonist activity in a cell line- and speciesspecific manner unlike TCDD (81, 82). Apigenin (a flavone), baicalein (a flavone), chrysin (a flavone), diosmetin (a flavone) and quercetin (a flavonol) are shown to activate the AhR (19) while keampferol (a flavonol), galangin (a flavonol) and naringenin (a flavanone) are demonstrated to antagonise the AhR and exhibit anti-cancer effects (83). Some flavonoids demonstrate dual AhR activity which further emphasizes the complexity of AhR responses in in vitro models. Opitz et al. demonstrated the pathophysiological role of $\mathrm{AhR}$ as a transducer of anti-tumor responses through activation by kynurenine (Kyn), a tryptophan (Trp) metabolite (84) which are both potent AhR agonists. However, emerging evidence reveals a role for AhR in halting malignant transformation and development of colorectal cancer (CRC). Metidji et al. demonstrated that application of AhR dietary ligand (I3C) can restore the Wnt- $\beta$-catenin signaling balance. The Wnt- $\beta$-catenin pathway is responsible for regulation of cell fate, proliferation, differentiation during developmental stages and tissue homeostasis (85). Deregulation of this signaling pathway has been strongly linked to many types of cancers (85) including CRC (48). In non-AhR studies, Wnt/$\beta$-catenin signaling has been affected by flavonoids such as quercetin and fisetin, apigenin and epigallocatechin gallate (a flavanol) (85). Overall, these reports suggest that flavonoidinduced immunomodulation may also have the potential to halt tumorigenesis in an AhR-dependent manner.

\section{Limitations}

Flavonoids are one group AhR ligands that have been shown to have therapeutic effects in various chronic inflammatory diseases. Therefore, further studies on the exact molecular mechanisms of action of flavonoids via AhR signaling is necessary to uncover the potential roles of AhR as an immune modulator. The majority of studies have been performed in immortalized cell lines and animal models which do not necessarily reflect immune responses by primary human cells/tissues (26). There is also evidence that flavonoids are selective AhR modulators which exhibit their agonist and antagonist activities and different potencies in tissue/organ/species-specific manner $(47,86)$. Therefore, it is difficult to predict their response selectivity on AhR as agonist or antagonist. Other factors which might limit the widespread acceptance of flavonoids as therapeutic agents include poor oral bioavailability and water solubility (87). Flavonoids generally have short half-lives in the human body. Hence, dietary intake of these flavonoids should be as regular as possible to maintain plasma concentrations sufficient to exert certain biological activities (87). Additionally, flavonoids can be recovered in large amounts using solvent extracts such as ethanol, methanol and acetone compared to water due to the different chemical characteristics and polarities (88). However, not all solvents are safe for consumption (89). Thus, various approaches have been taken into consideration, including application of novel drug delivery system such as nanoparticles and liposomes (87) that may help improve the bioavailability and solubility of flavonoids in human studies and unveil the full potential of these AhR ligands that can properly manipulate AhR signaling and improve disease outcomes. Curcumin, a phytochemical derived from Curcuma Longa has been extensively studied in nanoparticle drug delivery systems. Solid lipid nanoparticles (SLNPs) have been shown to improve the bioavailability, photostability, prevent degradation of curcumin plus target delivery to the tissue/cell of interest $(90,91)$. Encapsulation of curcumin by liposomes in rats demonstrated high bioavailability and more effective absorption compared to natural curcumin (92).

Herbal plants are a rich source of flavonoids. Celery, parsley, chamomile, mint and ginkgo biloba are herbs that contain high amounts of flavone (9). With modern scientific approaches, we could expand our scientific understanding of the medicinal effects of herbal plants at a molecular level considering their long history of usage and application as natural remedies for many diseases $(93,94)$.

\section{CONCLUDING REMARKS}

AhR responds to natural flavonoids in vivo and in vitro which can impact immune cell function and activation. Recent studies have suggested that AhR can control inflammatory responses and modulate the differentiation of multiple immune cells implicated in inflammatory diseases. Importantly, AhR offers a unique therapeutic opportunity for wide ranging chemical structures found in herbal medicine that may activate different immunomodulatory downstream pathways. We believe that the proper manipulation of AhR signaling from plant-based products could be the next promising strategy for treatment of many inflammatory diseases.

\section{AUTHOR CONTRIBUTIONS}

AC conceived the idea and provided input in mucosal immunology. NK provided the pharmacological input. RA provided the nutritional input. HG provided immunological input. IB wrote the draft which was reviewed by all authors. All authors contributed to the article and approved the submitted version.

\section{FUNDING}

AC is in receipt of a grant from the Herbal Research Group on In vitro evaluation of aryl hydrocarbon ligands in local plants (Grant Ref No. UBD/RSCH/URC/NIG/1.0/2019/005) potential immunomodulatory effects for $\$ 22,000$ (Brunei dollars) from 1st August 2019 to 31st July 2022. 


\section{REFERENCES}

1. Gonzalez H, Hagerling C, Werb Z. Roles of the Immune System in Cancer: From Tumor Initiation to Metastatic Progression. Genes Dev (2018) 32:126784. doi: 10.1101/GAD.314617.118

2. Pérez-Cano FJ, Castell M. Flavonoids, Inflammation and Immune System. Nutrients (2016) 8:8-11. doi: 10.3390/nu8100659

3. Vezza T, Rodríguez-Nogales A, Algieri F, Utrilla MP, Rodriguez-Cabezas ME, Galvez J. Flavonoids in Inflammatory Bowel Disease: A Review. Nutrients (2016) 8:1-22. doi: 10.3390/nu8040211

4. Rengasamy KRR, Khan H, Gowrishankar S, Lagoa RJL, Mahomoodally FM, Khan Z, et al. The Role of Flavonoids in Autoimmune Diseases: Therapeutic Updates. Pharmacol Ther (2019) 194:107-31. doi: 10.1016/j.pharmthera.2018.09.009

5. Wang XS, Cao F, Zhang Y, Pan HF. Therapeutic Potential of Aryl Hydrocarbon Receptor in Autoimmunity. Inflammopharmacology (2020) 28:63-81. doi: 10.1007/s10787-019-00651-z

6. Rodríguez-García C, Sánchez-Quesada C, Gaforio JJ, Gaforio JJ. Dietary Flavonoids as Cancer Chemopreventive Agents: An Updated Review of Human Studies. Antioxidants (2019) 8:1-23. doi: 10.3390/antiox8050137

7. Bisol Â, de Campos PS, Lamers ML. Flavonoids as Anticancer Therapies: A Systematic Review of Clinical Trials. Phytother Res (2020) 34:568-82. doi: $10.1002 /$ ptr.6551

8. Kopustinskiene DM, Jakstas V, Savickas A, Bernatoniene J. Flavonoids as Anticancer Agents. Nutrients (2020) 12:1-25. doi: 10.3390/nu12020457

9. Panche AN, Diwan AD, Chandra SR. Flavonoids: An Overview. J Nutr Sci (2016) 5:1-15. doi: 10.1017/jns.2016.41

10. Jantan I, Haque MA, Arshad L, Harikrishnan H, Septama AW, MohamedHussein ZA. Dietary Polyphenols Suppress Chronic Inflammation by Modulation of Multiple Inflammation-Associated Cell Signaling Pathways. J Nutr Biochem (2021) 93:108634. doi: 10.1016/j.jnutbio.2021.108634

11. Liu SH, Lin CH, Hung SK, Chou JH, Chi CW, Fu SL. Fisetin Inhibits Lipopolysaccharide-Induced Macrophage Activation and Dendritic Cell Maturation. J Agric Food Chem (2010) 58:10831-9. doi: 10.1021/jf1017093

12. Huang R-Y, Yu Y-L, Cheng W-C, OuYang C-N, Fu E, Chu C-L. Immunosuppressive Effect of Quercetin on Dendritic Cell Activation and Function. J Immunol (2010) 184:6815-21. doi: 10.4049/jimmunol.0903991

13. Xia N, Chen G, Liu M, Ye X, Pan Y, Ge J, et al. Anti-Inflammatory Effects of Luteolin on Experimental Autoimmune Thyroiditis in Mice. Exp Ther Med (2016) 12:4049-54. doi: 10.3892/etm.2016.3854

14. Wang J, Li TM, Zang L, Pan X, Wang S, Wu Y, et al. Apigenin Inhibits Human SW620 Cell Growth by Targeting Polyamine Catabolism. Evid Based Complement Alternat Med (2017) 2017:1-12. doi: 10.1155/2017/3684581

15. Hämäläinen $M$, Nieminen R, Vuorela $P$, Heinonen $M$, Moilanen E. AntiInflammatory Effects of Flavonoids: Genistein, Kaempferol, Quercetin, and Daidzein Inhibit STAT-1 and NF- $\mathrm{BB}$ Activations, Whereas Flavone, Isorhamnetin, Naringenin, and Pelargonidin Inhibit Only NF- $\kappa$ B Activation Along With Their Inhibitory Effect on I. Mediators Inflamm (2007) 2007:1-10. doi: 10.1155/2007/45673

16. Pei R, Liu X, Bolling B. Flavonoids and Gut Health. Curr Opin Biotechnol (2020) 61:153-9. doi: 10.1016/j.copbio.2019.12.018

17. Denison MS, Nagy SR. Activation of the Aryl Hydrocarbon Receptor by Structurally Diverse Exogenous and Endogenous Chemicals. Annu Rev Pharmacol Toxicol (2003) 43:309-34. doi: 10.1146/annurev.pharmtox.43.100901.135828

18. Nguyen LP, Bradfield CA. The Search for Endogenous Activators of the Aryl H. Chem Res Toxicol (2008) 21(1):102-16. doi: 10.1021/tx7001965

19. Jin UH, Park H, Li X, Davidson LA, Allred C, Patil B, et al. StructureDependent Modulation of Aryl Hydrocarbon Receptor-Mediated Activities by Flavonoids. Toxicol Sci (2018) 164:205-17. doi: 10.1093/toxsci/kfy075

20. Wheeler MA, Rothhammer V, Quintana FJ. Control of Immune-Mediated Pathology Via the Aryl Hydrocarbon Receptor. J Biol Chem (2017) 292:12383-9. doi: 10.1074/jbc.R116.767723

21. Poland A, Knutson JC. 2,3,7,8-Tetrachlorodibenzo- P -Dioxin and Related Halogenated Aromatic Hydrocarbons: Examination of the Mechanism of Toxicity. Annu Rev Pharmacol Toxicol (1982) 22:517-54. doi: 10.1146/ annurev.pa.22.040182.002505

22. Larigot L, Juricek L, Dairou J, Coumoul X. AhR Signaling Pathways and Regulatory Functions. Biochim Open (2018) 7:1-9. doi: 10.1016/ j.biopen.2018.05.001
23. Barroso A, Mahler JV, Fonseca-Castro PH, Quintana FJ. The Aryl Hydrocarbon Receptor and the Gut-Brain Axis. Cell Mol Immunol (2021) 18:259-68. doi: 10.1038/s41423-020-00585-5

24. Gutiérrez-Vázquez C, Quintana FJ. Regulation of the Immune Response by the Aryl Hydrocarbon Receptor. Immunity (2018) 48:19-33. doi: 10.1016/ j.immuni.2017.12.012

25. Rothhammer V, Quintana FJ. The Aryl Hydrocarbon Receptor: An Environmental Sensor Integrating Immune Responses in Health and Disease. Nat Rev Immunol (2019) 19:184-97. doi: 10.1038/s41577-0190125-8

26. Stockinger B, Di MP, Gialitakis M, Duarte JH. The Aryl Hydrocarbon Receptor: Multitasking in the Immune System. Annu Rev Immunol (2014) 32:403-32. doi: 10.1146/annurev-immunol-032713-120245

27. Hankinson O. Role of Coactivators in Transcriptional Activation by the Aryl Hydrocarbon Receptor. Arch Biochem Biophys (2005) 433:379-86. doi: 10.1016/j.abb.2004.09.031

28. Puga A, Barnes SJ, Dalton TP, Chang CY, Knudsen ES, Maier MA. Aromatic Hydrocarbon Receptor Interaction With the Retinoblastoma Protein Potentiates Repression of E2F-Dependent Transcription and Cell Cycle Arrest. J Biol Chem (2000) 275:2943-50. doi: 10.1074/jbc.275.4.2943

29. Vogel CFA, Sciullo E, Matsumura F. Involvement of RelB in Aryl Hydrocarbon Receptor-Mediated Induction of Chemokines. Biochem Biophys Res Commun (2007) 363:722-6. doi: 10.1016/j.bbrc.2007.09.032

30. Marlowe JL, Knudsen ES, Schwemberger S, Puga A. The Aryl Hydrocarbon Receptor Displaces p300 From E2F-Dependent Promoters and Represses S Phase-Specific Gene Expression. J Biol Chem (2004) 279:29013-22. doi: 10.1074/jbc.M404315200

31. Wright EJ, Pereira De Castro K, Joshi AD, Elferink CJ. Canonical and NonCanonical Aryl Hydrocarbon Receptor Signaling Pathways. Curr Opin Toxicol (2017) 2:87-92. doi: 10.1016/j.cotox.2017.01.001

32. Jackson DP, Li H, Mitchell KA, Joshi AD, Elferink CJ. Ah Receptor-Mediated Suppression of Liver Regeneration Through NC-XRE-Driven p21Cip1 Expression. Mol Pharmacol (2014) 85:533-41. doi: 10.1124/mol.113.089730

33. Garcia GR, Goodale BC, Wiley MW, La Du JK, Hendrix DA, Tanguay RL. In Vivo Characterization of an AHR-Dependent Long Noncoding RNA Required for Proper Sox9b Expression. Mol Pharmacol (2017) 91:609-19. doi: $10.1124 / \mathrm{mol} .117 .108233$

34. Wang S, Hankinson O. Functional Involvement of the Brahma/SWI2-Related Gene 1 Protein in Cytochrome P4501A1 Transcription Mediated by the Aryl Hydrocarbon Receptor Complex. J Biol Chem (2002) 277:11821-7. doi: $10.1074 /$ jbc.M110122200

35. Beischlag TV, Wang S, Rose DW, Torchia J, Reisz-Porszasz S, Muhammad K, et al. Recruitment of the NCoA/SRC-1/p160 Family of Transcriptional Coactivators by the Aryl Hydrocarbon Receptor/Aryl Hydrocarbon Receptor Nuclear Translocator Complex. Mol Cell Biol (2002) 22:4319-33. doi: $10.1128 / \mathrm{mcb} .22 .12 .4319-4333.2002$

36. Schnekenburger M, Peng L, Puga A. HDAC1 Bound to the Cypla1 Promoter Blocks Histone Acetylation Associated With Ah Receptor-Mediated TransActivation. Biochim Biophys Acta - Gene Struct Expr (2007) 1769:569-78. doi: 10.1016/j.bbaexp.2007.07.002

37. Murray IA, Reen RK, Leathery N, Ramadoss P, Bonati L, Gonzalez FJ, et al. Evidence That Ligand Binding Is a Key Determinant of Ah ReceptorMediated Transcriptional Activity. Arch Biochem Biophys (2005) 442:59-71. doi: 10.1016/j.abb.2005.07.014

38. Han Z, Miwa Y, Obikane H, Mitsumata M, Takahashi-Yanaga F, Morimoto S, et al. Aryl Hydrocarbon Receptor Mediates Laminar Fluid Shear StressInduced CYP1A1 Activation and Cell Cycle Arrest in Vascular Endothelial Cells. Cardiovasc Res (2008) 77:809-18. doi: 10.1093/cvr/cvm095

39. Stockinger B, Hirota K, Duarte J, Veldhoen M. External Influences on the Immune System Via Activation of the Aryl Hydrocarbon Receptor. Semin Immunol (2011) 23:99-105. doi: 10.1016/j.smim.2011.01.008

40. Gandhi R, Kumar D, Burns EJ, Nadeau M, Dake B, Laroni A, et al. Activation of the Aryl Hydrocarbon Receptor Induces Human Type 1 Regulatory T CellLike and Foxp3+ Regulatory T Cells. Nat Immunol (2010) 11:846-53. doi: 10.1038/ni.1915

41. Quintana FJ, Basso AS, Iglesias AH, Korn T, Farez MF, Bettelli E, et al. Control of Treg and TH17 Cell Differentiation by the Aryl Hydrocarbon Receptor. Nature (2008) 453:65-71. doi: 10.1038/nature06880 
42. Mascanfroni ID, Takenaka MC, Yeste A, Patel B, Wu Y, Kenison JE, et al. Metabolic Control of Type 1 Regulatory T Cell Differentiation by AHR and HIF1- $\alpha$. Nat Med (2015) 21:638-46. doi: 10.1038/nm.3868

43. Basu R, O'Quinn DB, Silberger DJ, Schoeb TR, Fouser L, Ouyang W, et al. Th22 Cells Are an Important Source of IL-22 for Host Protection Against Enteropathogenic Bacteria. Immunity (2012) 37:1061-75. doi: 10.1016/ j.immuni.2012.08.024

44. Winans B, Nagari A, Chae M, Post CM, Ko C-I, Puga A, et al. Linking the Aryl Hydrocarbon Receptor With Altered DNA Methylation Patterns and Developmentally Induced Aberrant Antiviral CD8 + T Cell Responses. J Immunol (2015) 194:4446-57. doi: 10.4049/jimmunol.1402044

45. Vaidyanathan B, Chaudhry A, Yewdell WT, Angeletti D, Yen WF, Wheatley AK, et al. The Aryl Hydrocarbon Receptor Controls Cell-Fate Decisions in B Cells. J Exp Med (2017) 214:197-208. doi: 10.1084/jem.20160789

46. Jiang YZ, Wang K, Fang R, Zheng J. Expression of Aryl Hydrocarbon Receptor in Human Placentas and Fetal Tissues. J Histochem Cytochem (2010) 58:679-85. doi: 10.1369/jhc.2010.955955

47. Esser C, Rannug A. The Aryl Hydrocarbon Receptor in Barrier Organ Physiology, Immunology, and Toxicology. Pharmacol Rev (2015) 67:25979. doi: $10.1124 /$ pr.114.009001

48. Metidji A, Omenetti S, Crotta S, Li Y, Nye E, Ross E, et al. The Environmental Sensor AHR Protects From Inflammatory Damage by Maintaining Intestinal Stem Cell Homeostasis and Barrier Integrity. Immunity (2018) 49:353-62.e5. doi: 10.1016/j.immuni.2018.07.010

49. Li Y, Innocentin S, Withers DR, Roberts NA, Gallagher AR, Grigorieva EF, et al. Exogenous Stimuli Maintain Intraepithelial Lymphocytes Via Aryl Hydrocarbon Receptor Activation. Cell (2011) 147:629-40. doi: 10.1016/ j.cell.2011.09.025

50. Li S, Bostick JW, Zhou L. Regulation of Innate Lymphoid Cells by Aryl Hydrocarbon Receptor. Front Immunol (2018) 8:1909. doi: 10.3389/ fimmu.2017.01909

51. Suh J, Jeon YJ, Kim HM, Kang JS, Kaminski NE, Yang KH. Aryl Hydrocarbon Receptor-Dependent Inhibition of AP-1 Activity by 2,3,7,8Tetrachlorodibenzo-P-Dioxin in Activated B Cells. Toxicol Appl Pharmacol (2002) 181:116-23. doi: 10.1006/taap.2002.9403

52. Boverhof DR, Tam E, Harney AS, Crawford RB, Kaminski NE, Zacharewski TR. 2,3,7,8-Tetrachlorodibenzo-p-dioxin Induces Suppressor of Cytokine Signaling 2 in Murine B Cells. Mol Pharmacol (2004) 66:1662-70. doi: 10.1124/mol.104.002915

53. Nguyen NT, Kimura A, Nakahama T, Chinen I, Masuda K, Nohara K, et al. Aryl Hydrocarbon Receptor Negatively Regulates Dendritic Cell Immunogenicity Via a Kynurenine-Dependent Mechanism. Proc Natl Acad Sci USA (2010) 107:19961-6. doi: 10.1073/pnas.1014465107

54. Thatcher TH, Williams MA, Pollock SJ, Mccarthy CE, Lacy SH, Phipps RP, et al. Endogenous Ligands of the Aryl Hydrocarbon Receptor Regulate Lung Dendritic Cell Function. Immunology (2016) 147:41-54. doi: 10.1111/imm.12540

55. Jurado-Manzano BB, Zavala-Reyes D, Turrubiartes-Martínez EA, PortalesPérez DP, González-Amaro R, Layseca-Espinosa E. FICZ Generates Human tDCs That Induce CD4+ CD25high Foxp3+ Treg-Like Cell Differentiation. Immunol Lett (2017) 190:84-92. doi: 10.1016/j.imlet.2017.07.013

56. de Araújo EF, Feriotti C, de Lima Galdino NA, Preite NW, Calich VLG, Loures FV. The IDO-AhR Axis Controls Th17/Treg Immunity in a Pulmonary Model of Fungal Infection. Front Immunol (2017) 8:880. doi: 10.3389/fimmu.2017.00880

57. Wang C, Ye Z, Kijlstra A, Zhou Y, Yang P. Activation of the Aryl Hydrocarbon Receptor Affects Activation and Function of Human Monocyte-Derived Dendritic Cells. Clin Exp Immunol (2014) 177:521-30. doi: 10.1111/cei.12352

58. Hayday AC. $\gamma \delta$ T Cell Update: Adaptate Orchestrators of Immune Surveillance. J Immunol (2019) 203:311-20. doi: 10.4049/jimmunol.1800934

59. Martin B, Hirota K, Cua DJ, Stockinger B, Veldhoen M. Interleukin-17Producing $\gamma \delta$ T Cells Selectively Expand in Response to Pathogen Products and Environmental Signals. Immunity (2009) 31:321-30. doi: 10.1016/ j.immuni.2009.06.020

60. Marshall NB, Kerkvliet NI. Dioxin And Immune Regulation: Emerging Role Of Aryl Hydrocarbon Receptor in the Generation of Regulatory T Cells. Ann NY Acad Sci (2010) 1183:25-37. doi: 10.1111/j.1749-6632.2009.05125.x

61. Denison MS, Soshilov AA, He G, Degroot DE, Zhao B. Exactly the Same But Different: Promiscuity and Diversity in the Molecular Mechanisms of Action of the Aryl Hydrocarbon (Dioxin) Receptor. Toxicol Sci (2011) 124:1-22. doi: $10.1093 /$ toxsci/kfr218

62. Gabriely G, Wheeler MA, Takenaka MC, Quintana FJ. Role of AHR and HIF$1 \alpha$ in Glioblastoma Metabolism. Trends Endocrinol Metab (2017) 28:428-36. doi: 10.1016/j.tem.2017.02.009

63. Veldhoen M, Hirota K, Westendorf AM, Buer J, Dumoutier L, Renauld JC, et al. The Aryl Hydrocarbon Receptor Links TH17-Cell-Mediated Autoimmunity to Environmental Toxins. Nature (2008) 453:106-9. doi: 10.1038/nature06881

64. Veldhoen M, Hirota K, Christensen J, O'Garra A, Stockinger B. Natural Agonists for Aryl Hydrocarbon Receptor in Culture Medium Are Essential for Optimal Differentiation of Th17 T Cells. J Exp Med (2009) 206:43-9. doi: $10.1084 /$ jem. 20081438

65. Wolk K, Haugen HS, Xu W, Witte E, Waggie K, Anderson M, et al. IL-22 and IL-20 Are Key Mediators of the Epidermal Alterations in Psoriasis While IL17 and IFN- $\gamma$ Are Not. J Mol Med (2009) 87:523-36. doi: 10.1007/s00109-0090457-0

66. Zenewicz LA, Flavell RA. Recent Advances in IL-22 Biology. Int Immunol (2011) 23:159-63. doi: 10.1093/intimm/dxr001

67. Zelante T, Iannitti RG, Cunha C, DeLuca A, Giovannini G, Pieraccini G, et al. Tryptophan Catabolites From Microbiota Engage Aryl Hydrocarbon Receptor and Balance Mucosal Reactivity Via Interleukin-22. Immunity (2013) 39:37285. doi: 10.1016/j.immuni.2013.08.003

68. Lamas B, Richard ML, Leducq V, Pham HP, Michel ML, Da Costa G, et al. CARD9 Impacts Colitis by Altering Gut Microbiota Metabolism of Tryptophan Into Aryl Hydrocarbon Receptor Ligands. Nat Med (2016) 22:598-605. doi: 10.1038/nm.4102

69. Shinde R, McGaha TL. The Aryl Hydrocarbon Receptor: Connecting Immunity to the Microenvironment. Trends Immunol (2018) 39:1005-20. doi: 10.1016/j.it.2018.10.010

70. Shinde R, Hezaveh K, Halaby MJ, Kloetgen A, Chakravarthy A, Da Silva Medina T, et al. Apoptotic Cell-Induced AhR Activity Is Required for Immunological Tolerance and Suppression of Systemic Lupus Erythematosus in Mice and Humans Article. Nat Immunol (2018) 19:57182. doi: 10.1038/s41590-018-0107-1

71. Kawai S, Iijima H, Shinzaki S, Hiyama S. Indigo Naturalis Ameliorates Murine Dextran Sodium Sulfate-Induced Colitis Via Aryl Hydrocarbon Receptor Activation. J Gastroenterol (2016) 52:904-19. doi: 10.1007/s00535-016$1292-\mathrm{z}$

72. Lin YH, Luck H, Khan S, Schneeberger PHH, Tsai S, Clemente-Casares X, et al. Aryl Hydrocarbon Receptor Agonist Indigo Protects Against Obesity-Related Insulin Resistance Through Modulation of Intestinal and Metabolic Tissue Immunity. Int J Obes (2019) 43:2407-21. doi: 10.1038/s41366-019-0340-1

73. Domínguez-Acosta O, Vega L, Estrada-Muñiz E, Rodríguez MS, Gonzalez FJ, Elizondo G. Activation of Aryl Hydrocarbon Receptor Regulates the LPS/ IFN $\gamma$-Induced Inflammatory Response by Inducing Ubiquitin-Proteosomal and Lysosomal Degradation of RelA/P65. Biochem Pharmacol (2018) 155:141-9. doi: 10.1016/j.bcp.2018.06.016

74. Wang K, Lv Q, Miao Ym, Qiao Sm, Dai Y, Wei Zf. Cardamonin, a Natural Flavone, Alleviates Inflammatory Bowel Disease by the Inhibition of NLRP3 Inflammasome Activation Via an AhR/Nrf2/NQO1 Pathway. Biochem Pharmacol (2018) 155:494-509. doi: 10.1016/j.bcp.2018.07.039

75. Lv Q, Shi C, Qiao S, Cao N, Guan C, Dai Y, et al. Alpinetin Exerts Anti-Colitis Efficacy by Activating AhR, Regulating miR-302/DNMT-1/CREB Signals, and Therefore Promoting Treg Differentiation. Cell Death Dis (2018) 9:1-25. doi: 10.1038/s41419-018-0814-4

76. Wang HK, Yeh CH, Iwamoto T, Satsu H, Shimizu M, Totsuka M. Dietary Flavonoid Naringenin Induces Regulatory T Cells Via an Aryl Hydrocarbon Receptor Mediated Pathway. J Agric Food Chem (2012) 60:2171-8. doi: 10.1021/j2204625y

77. Miron A, Aprotosoaie AC, Trifan A, Xiao J. Flavonoids as Modulators of Metabolic Enzymes and Drug Transporters. Ann NY Acad Sci (2017) 1398:152-67. doi: 10.1111/nyas.13384

78. Van Der Woude H, Boersma MG, Vervoort J, Rietjens IMCM. Identification of 14 Quercetin Phase II Mono- and Mixed Conjugates and Their Formation by Rat and Human Phase II In Vitro Model Systems. Chem Res Toxicol (2004) 17:1520-30. doi: 10.1021/tx049826v

79. Murota K, Nakamura Y, Uehara M. Flavonoid Metabolism: The Interaction of Metabolites and Gut Microbiota. Biosci Biotechnol Biochem (2018) 82:600-10. doi: $10.1080 / 09168451.2018 .1444467$ 
80. Ray SK, Mukherjee S. Evolving Interplay Between Dietary Polyphenols and Gut Microbiota-An Emerging Importance in Healthcare. Front Nutr (2021) 8:197-203. doi: 10.3389/fnut.2021.634944

81. Murray IA, Patterson AD, Perdew GH. Aryl Hydrocarbon Receptor Ligands in Cancer: Friend and Foe. Nat Rev Cancer (2014) 14:801-14. doi: 10.1038/ $\operatorname{nrc} 3846$

82. Zhang S, Qin C, Safe SH. Brogan \& Partners Flavonoids as Aryl Hydrocarbon Receptor Agonists/Antagonists: Effects of Structure and Cell Context. Environ Health Perspect (2014) 111:1877-82. doi: 10.1289/ehp.6322

83. Zhang S, Qin C, Safe SH. Flavonoids as Aryl Hydrocarbon Receptor Agonists/ Antagonists: Effects of Structure and Cell Context. Environ Health Perspect (2003) 111:1877-82. doi: 10.1289/ehp.6322

84. Opitz CA, Litzenburger UM, Sahm F, Ott M, Tritschler I, Trump S, et al. An Endogenous Tumour-Promoting Ligand of the Human Aryl Hydrocarbon Receptor. Nature (2011) 478:197-203. doi: 10.1038/nature10491

85. Amado NG, Fonseca BF, Cerqueira DM, Neto VM, Abreu JG. Flavonoids: Potential Wnt/Beta-Catenin Signaling Modulators in Cancer. Life Sci (2011) 89:545-54. doi: 10.1016/j.lfs.2011.05.003

86. Safe S, Jin UH, Park H, Chapkin RS, Jayaraman A. Aryl Hydrocarbon Receptor (AHR) Ligands as Selective Ahr Modulators (SAHRMS). Int J Mol Sci (2020) 21:1-16. doi: 10.3390/ijms21186654

87. Yang T, Feng YL, Chen L, Vaziri ND, Zhao YY. Dietary Natural Flavonoids Treating Cancer by Targeting Aryl Hydrocarbon Receptor. Crit Rev Toxicol (2019) 49:445-60. doi: 10.1080/10408444.2019.1635987

88. Altemimi A, Lakhssassi N, Baharlouei A, Watson DG, Lightfoot DA. Phytochemicals: Extraction, Isolation, and Identification of Bioactive Compounds From Plant Extracts. Plants (2017) 6:445-60. doi: 10.3390/ plants6040042

89. Do QD, Angkawijaya AE, Tran-Nguyen PL, Huynh LH, Soetaredjo FE, Ismadji S, et al. Effect of Extraction Solvent on Total Phenol Content, Total
Flavonoid Content, and Antioxidant Activity of Limnophila Aromatica. J Food Drug Anal (2014) 22:296-302. doi: 10.1016/j.jfda.2013.11.001

90. Ahmad MZ, Alkahtani SA, Akhter S, Ahmad FJ, Ahmad J, Akhtar MS, et al. Progress in Nanotechnology-Based Drug Carrier in Designing of Curcumin Nanomedicines for Cancer Therapy: Current State-of-the-Art. J Drug Target (2016) 24:273-93. doi: 10.3109/1061186X.2015.1055570

91. Coradini K, Lima FO, Oliveira CM, Chaves PS, Athayde ML, Carvalho LM, et al. Co-Encapsulation of Resveratrol and Curcumin in Lipid-Core Nanocapsules Improves Their In Vitro Antioxidant Effects. Eur J Pharm Biopharm (2014) 88:178-85. doi: 10.1016/j.ejpb.2014.04.009

92. Takahashi M, Uechi S, Takara K, Asikin Y, Wada K. Evaluation of an Oral Carrier System in Rats: Bioavailability and Antioxidant Properties of Liposome-Encapsulated Curcumin. J Agric Food Chem (2009) 57:9141-6. doi: 10.1021/jf9013923

93. Ko SG, Yin CS, Du B, Kim K. Herbal Medicines for Inflammatory Diseases. Mediators Inflamm (2014) 2014:982635. doi: 10.1155/2014/982635

94. Li F, Weng J. Demystifying Traditional Herbal Medicine With. Nat Publ Group (2017) 3:1-7. doi: 10.1038/nplants.2017.109

Conflict of Interest: The authors declare that the research was conducted in the absence of any commercial or financial relationships that could be construed as a potential conflict of interest.

Copyright (c) 2021 Bungsu, Kifli, Ahmad, Ghani and Cunningham. This is an openaccess article distributed under the terms of the Creative Commons Attribution License (CC BY). The use, distribution or reproduction in other forums is permitted, provided the original author(s) and the copyright owner(s) are credited and that the original publication in this journal is cited, in accordance with accepted academic practice. No use, distribution or reproduction is permitted which does not comply with these terms. 